\title{
Effects of Unbalanced and Balanced Applied Loads on Norbergs Angle in Ventrodorsal Hip-Extended Radiographies
}

\author{
M. Volkan YAPRAKCI ${ }^{1 *}$, Marek GALANTY2 \\ ${ }^{1}$ Afyon Kocatepe University, Veterinary Faculty, Surgery Department, 03200, Gazllgöl Province, Turkey \\ ${ }^{2}$ Szkoła Gtowna Gospodarstwa Wiejskiego, Warsaw, Poland, Nowoursynowska 166, 02-787 Warszawa, Poland
}

\begin{abstract}
Two radiographic distraction techniques (Standard Ventrodorsal Hip-Extended Radiography, SHER, and Balanced Hip-Extended Radiography, BHER) were evaluated for Canine Hip Dysplasia (CHD) diagnosis on 100 hip joints of 50 dogs to determine the most reliable method in the detection of higher hip laxity employing Norbergs-Olsson angle (NoA) evaluation (FCI hip scoring). Anesthesia was standardized due to uniformity in muscle relaxation and applied to extend loads (SHERKg and BHERKg) were measured on hind legs using electronic weight scales (EWS) simultaneously with ventrodorsal (V/D) radiography. Results of NoA scores were evaluated statistically together with weight scale (WS) values. Significant differences were found between groups of methods for both in WS results $(\mathrm{p}<.001)$ and NoA evaluations $(\mathrm{p}<.001)$. The difference between right and left sides in WS results was not found significant ( $\mathrm{p}>$.05). Even if there was no significant difference occurred in this, balancing the loads with the BHER method caused a significant difference in NoA values between tested methods $(\mathrm{p}<.001)$. Moreover, the linear, positive, and strong correlation between SHER and BHER methods was shown the reliability of the BHER method in NoA evaluations $(\mathrm{rs}=.910, \mathrm{p}<.001)$. In conclusion, by having a positive and strong correlation with the standard method, and better outcomes in FCI hip scoring with lower misdiagnose frequency thus affecting the clinical outcome, the BHER method was offered as a reliable method in the diagnosis of CHD.
\end{abstract}

Keywords: canine hip dysplasia, norberg's angle, balanced hip extended, ventrodorsal hip extended, radiography

\section{Dengelenmış ve Dengesiz Gerilim Kuvvetlerinin Köpeklerde Ventro-Dorsal Kalça Görüntülenmesinde Norbergs Açısı Üzerine Etkileri}

\section{ÖZ}

İki radyografik distraksiyon tekniği (Standart, SHER ve Dengelenmiş Radyografi, BHER) köpek kalça displazisinin değerlendirilmesinde 50 köpeğin 100 kalça ekleminde değerlendirildi ve sonuçlar Norberg-Olsson (NoA) açı derecesi temelinde ele alındı (FCI skorlama). Anestezik yöntem kas gevşemesi yönünden standardize uygulandi. Arka ayaklara uygulanan çekme kuvvetleri (SHERKg ve BHERKg) radyografiler sirasında elektronik yük ölçer (WS) alet vasıtası ile ölçüldü. NoA ölçüm sonuçları yük ölçer sonuçları birlikte istatistiksel yönden değerlendirildi. NoA açısı $(\mathrm{p}<.001)$ ve WS sonuçlarında gruplar arasında istatistiksel yönden anlamlı sonuçlar belirlendi. WS sonuçlarında sağ ve sol ayak tarafları arasında fark belirlenmedi ( $\mathrm{p}>.05$ ). BHER metodunda kullanılan dengeleyici çekme kuvveti sonucunda NoA ölçümlerinde anlamlı farklılık oluştuğu görüldü $(\mathrm{p}<.001)$. SHER ve BHER metodları arasında istatistiksel yönden lineer, pozitif ve güçlü bir korrelasyon bulunması BHER metodunun güvenilirliği yönünde değerlendirildi $(r s=.910, \mathrm{p}<.001)$. Karar aşamasında; uygulanan BHER metodunun FCI skorlaması yönünden daha az yanlış tanı bulgusu göstermesi neticesinde klinik aşamada köpek kalça displazisinin belirlenmesinde güvenilir bir metod olduğu ve meslektaşlarımıza önerilebileceği sonucuna varild1.

Anahtar kelimeler: köpek kalça displazisi, norbergs açısı, dengelenmiş kalça gerdirme, ventrodorsal kalça gerdirme, radyografi

To cite this article: Yaprakec M.V. Galanty M. Effects of Unbalanced and Balanced Applied Loads on Norbergs Angle in Ventrodorsal HipExtended Radiographies. Kocatepe Vet J. (2020) 13(4)426432

Submission: 08.05.2020 Accepted: 23.11.2020 Published Online: 26.11.2020

ORCID ID; MVY: 0000-0003-2793-4295, MG: 0000-0002-9879-9417

*Corresponding author e-mail: mvyaprakci@aku.edu.tr 


\section{INTRODUCTION}

Canine hip dysplasia (CHD) is frequently seen as one of the most common developmental hereditary diseases in dogs which can lead to debilitating osteoarthritis in the advanced stage. Early diagnosis is crucial in the evaluation of the CHD (Farese et al. 1998, Smith et al. 1993). Many clinical reports and studies have been published about early diagnosis of Canine Hip Dysplasia in comparison with palpation and radiographic methods (Adams et al. 1998, Corfield et al. 2007, Culp et al. 2006, Meomartino et al. 2002, Ohlerth et al. 2003, Reagan 2017, Thompson et al. 2007, Verhoeven et al. 2007) in the diagnosis of hip laxity, which is one of the predictors of secondary joint disease (Dueland et al. 2001). The degree of hip joint subluxation is a predictive risk factor for CHD expression in $\operatorname{dogs}$ as young as 16 weeks of age (Reagan 2017, Risler et al. 2009). Many genetic screening programs and study groups such as Federation Cynologique Internationale (FCI) and Pennsylvania Hip Screening Program (Penn-Hip) have utilized various radiographic methods for the evaluation of joint laxity and defined the criteria for several classifications in the diagnosis of Canine Hip Dysplasia (Adams et al. 1998, Farese et al. 1998, Reagan 2017, Risler et al. 2009, Yaprakci and Tekerli 2015). CHD is frequently evaluated based on SHER (Adams et al. 1998, Genevois et al. 2007, Genevois et al. 2008) and hip laxity is measured employing Norbergs-Olsson Angle (NoA) (Culp et al. 2006, Genevois et al. 2006, Verhoeven et al. 2007). Norberg Angle is found to be not an accurate predictor of canine hip conformation based on distraction index and dorsolateral subluxation score (Gaspar et al. 2016). A basis deficit of Standard V/D Hip-Extended Radiography remains unnoticed till today.

The main aim of this study was to demonstrate the difference of hip scores between two tested radiography methods (SHER and BHER) using NoA measurements according to Federation Cynologique Internationale (FCI) recommendations. The results of applied loads used to extend hind legs were conducted with associated NoA evaluations. Differences and correlations of the groups were evaluated statistically.

\section{MATERIALS and METHODS}

This study was carried out by the principles of the Basel Declaration and recommendations of Warsaw University of Life Sciences, Faculty of Veterinary Medicine Animal Hospital Guidelines and the diagnostic protocol was approved by the Head Committee for Clinical Studies in 2008. All subjects' owners gave written informed consent under the Declaration of Helsinki. A comparative study was held on 100 hip joints of 50 dogs from different breed, sex, and age that were brought to clinics for canine hip dysplasia evaluation. The mean age was 20.2 months old and the mean bodyweight of the group was $30.12 \mathrm{Kg}$ (Std. Error=1.77, Std. Deviation=12.54). Cases were anesthetized using a standard combination of dexmedetomidine (Dexdomitor ${ }^{\mathrm{tm}}$, Pfizer, $325 \mathrm{ug} / \mathrm{m} 2$ ), butorphanol (Butomidor 0.2-0.4 $\mathrm{mg} / \mathrm{Kg}$ ) and midazolam (Dormicum $^{\mathrm{tm}}$, Roche $0.1-0.25 \mathrm{mg} / \mathrm{Kg}$ ) administrated intravenously. Referring to the sedation scale that is used in a related study (Genevois et al. 2006) an excellent muscle relaxation is crucial and was chosen for the convenient radiography procedure for all cases. WS measurements were obtained simultaneously with radiographs. A slight inward rotation to hind legs was supplied to centralize the kneecaps on femoral notches. This was done by hobbling the hind limbs with a string at the level of stifle joints (Figure 1, ty). A cloth strap (cs) was tautened over the stifle joints to stabilize the back part of the animal on the table and to parallel hind legs to the table (Figure 1, cs). Legs were tied with band strings (Figure 1, c) connected over EWS (Figure 1, EWS) to the adjustable poles (p) of the radiography table (Figure 1, p). The WS measurements were registered in kilograms within the accuracy of two decimals.

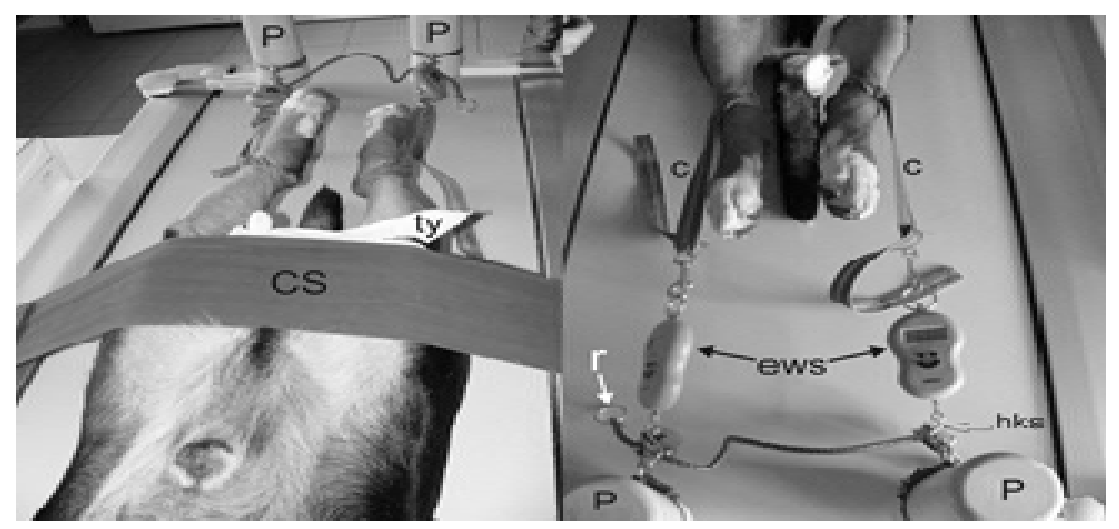

Figure 1. Ventrodorsal hip-extended radiography procedure and weight scale evaluation

Figure 1, Legend: cs: cloth strap, ty: hobbling string, p: table poles, hks: hook, ews: electronic weigth scale (two sides) 
Two types of methods (SHER and BHER) were taken consecutively. None of the elements used to stabilize the patient on the table were changed between methods. In BHER, radiographs were taken using the "Balance Distractor" device on hind legs. The Balance Distractor device (Figure 1) was made of two pulleys (Figure 2, pu) and a string (Figure 2, a) passing through these pulleys which were attached to the pole rings (Figure 2, pr). On both ends of the string, there were rings (Figure 1, r) to supply an attachment to the hooks of EWS. In performing the radiography, firstly SHER evaluation was made and the hooks of the WSs (Figure 1, Figure 2, hks) were detached from pole rings (Figure 2, pr) by relaxing the poles and subsequently re-attached to the rings (Figure 1, r) of the string (Figure 2, a) of the Balance Distractor device to perform BHER method. The second measurement of WS was done for the BHER method in the same manner as it was done for the SHER method.

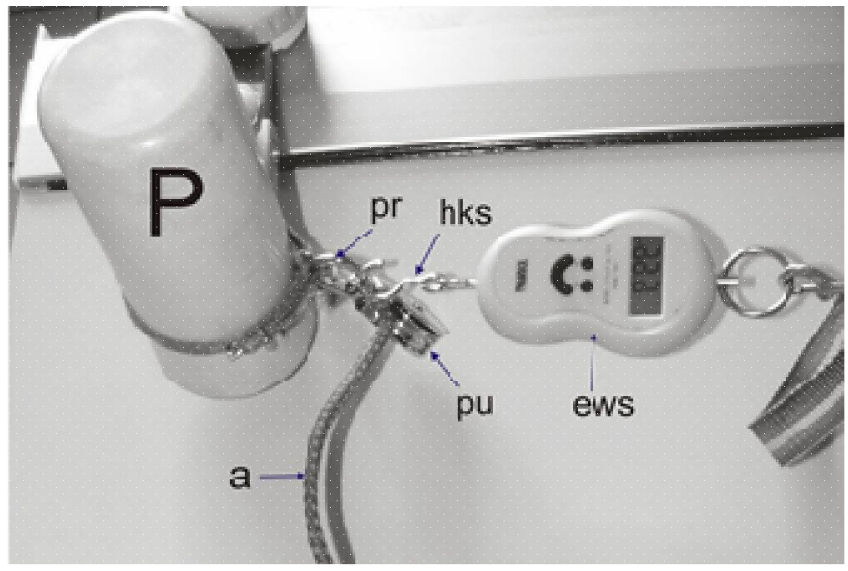

Figure 2. Parts of the Balance Distractor device (single side represented)

Figure 2, Legend: ews: electronic weight scale, pu: pulley, hks: hook, pr: pole ring, a: string of the balance distractor, p: pole

All radiographs were taken by digital radiography device (GE Prestige II, General Electric Company, Easton Turnpike Fairfield, Connecticut, USA) and by radiology technicians that were unaware about the features of the study to avoid flank judgment. NoA measurements were obtained by a radiologist as in guideline described in related studies (Adams et al. 1998, Culp et al. 2006, Henry 1992, Verhoeven et al. 2007) using a standard measuring template and 1 degree of accuracy was chosen for the evaluation. The rotated radiographs were repeated and found concurrent diseases such as pelvic fractures, obvious degenerative joint disease, or coxofemoral luxations were excluded from the study. The normality of the data was tested with the Kolmogorov-Smirnov test. To compare differences between the NoA angles of SHER and BHER methods, Wilcoxon Signed Rank test was used. To compare differences of the WS used with SHER and BHER methods, paired sample test was used. To find out the relationship between NoA angles of SHER and BHER methods, Spearmans rho coefficient (rs) was used. To find out the relationship between the WS values between methods, Pearson correlation coefficient(r) was used. The joints were considered as dysplastic if $105^{\circ}<\mathrm{NoA}$ value was observed for clinical results evaluation. SPSS 12.0 software was used for statistical evaluations.

\section{RESULTS}

The groups' descriptive values were represented in Table

Table 1: Descriptive values for the study groups

\begin{tabular}{lllll}
\hline Descriptive Statistics & & & & \\
\hline Study Groups & SHERKG & BHERKG & SHERNoA & BHERNoA \\
$\mathbf{N}$ & 100 & 100 & 100 & 100 \\
Mean & 4,1730 & 1,9750 & 98,0347 & 95,6582 \\
Std. Error of Mean &, 21814 &, 04722 & 1,10584 & 1,04710 \\
Median & 3,7500 & 1,9000 & 100,5850 & 97,4750 \\
Std. Deviation & 2,18137 &, 47221 & 11,05839 & 10,47095 \\
Minimum &, 62 & 1,00 & 72,76 & 71,64 \\
Maximum & 9,55 & 2,99 & 122,62 & 116,30 \\
\hline
\end{tabular}

Legend: std.: standard, N: number, SHERKG: Standard Hip Extended Kg, BHERKG: Balanced Hip Extended Kg, SHERNoA: Standard Hip Extended Norbergs Angle, BHERNoA: Balanced Hip Extended Norbergs Angle 
Significant difference was found between BHERKg $(\mathrm{M}=1.97, \quad \mathrm{SE}=.47)$ and $\mathrm{SHERKg}(\mathrm{M}=$ 4.17, $\mathrm{SE}=0.22), \mathrm{t}(99)=-10,45, \mathrm{p}<.001, \mathrm{r}=-0.72$. However when the differencebetween right and left hip sides taken into account by loads, SHERKgRight $(\mathrm{M}=3,8404, \quad \mathrm{SE}=0,3271)$ and SHERKgLeft
$(\mathrm{M}=4,5056, \mathrm{SE}=0,337), \mathrm{t}(49)=-1.916, \mathrm{p}>.05, \mathrm{r}=-$ 0.26 , and the difference between BHERKgRight $(\mathrm{M}=1,9690, \quad \mathrm{SE}=0, \quad 065)$ and BHERKgLeft $(\mathrm{M}=1,9810, \mathrm{SE}=0,068), \mathrm{t}(49)=-0.719, \mathrm{p}>.05, \mathrm{r}=-$ 0.10 , was not found statistically significant (Table 2).

Table 2: Detailed descriptive values for weight scale evaluations

\section{Descriptive Statistics}

\begin{tabular}{lllll}
\hline WS groups & Mean & $\mathrm{N}$ & Std. Deviation & Std. Error Mean \\
SHERKgRight & 3,8404 & 50 & 1,91989 &, 27151 \\
SHERKgLeft & 4,5056 & 50 & 2,38790 &, 33770 \\
BHERKgRight & 1,9690 & 50 &, 46355 &, 06556 \\
BHERKgLeft & 1,9810 & 50 &, 48535 &, 06864 \\
\hline
\end{tabular}

Legend: std: standard, N: number, WS: weight scale, SHERKG: Standard Hip Extended Kg, BHERKG: Balanced Hip Extended Kg

The study showed that there was a statistically significant difference between SHERNoA (Median=100.59) and BHERNoA (Median=97.48), $\mathrm{z}=-5.089, \mathrm{p}<.001, \mathrm{r}=-0.76$. A significant, positive, and strong correlation was found between SHERNoA and BHERNoA, $\mathrm{rs}=.910, \mathrm{p}<.001$ (Figure

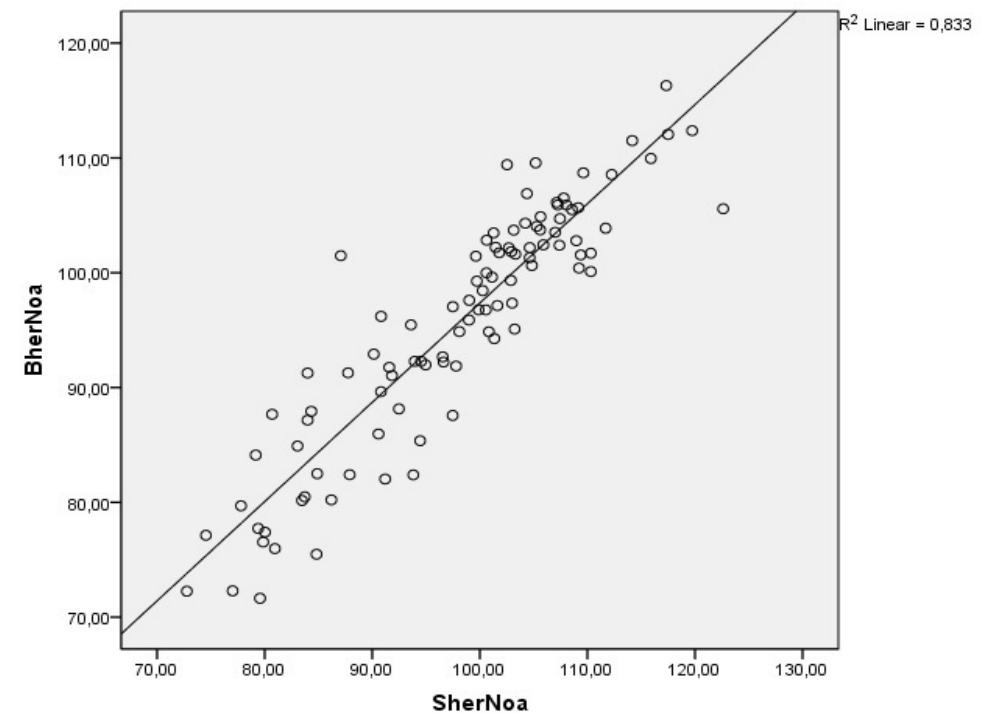

Figure 3. Graph of the correlation between SHERNoA and BHERNoA.

Figure 3, Legend: BHERNoa: Balanced Hip Extended Norbergs Angle Values, SHERNoa: Standard Hip Extended Norbergs Angle Values

In clinical results, according to the SHER method, 72 hip joints $(72 \%)$ were found diseased and 28 hip joints $(\% 28)$ were healthy, according to the BHER method; 83 hip joints $(83 \%)$ were found diseased and $17(\% 17)$ were healthy. The 72 diseased hip joints of the SHER method were also found as diseased by
$97.2 \%$ (70 joints) but yet 2 joints $(2.8 \%$ ) of this group were healthy according to the BHER method. The 28 healthy hip joints in the SHER method were also found as healthy with the BHER method by $53.6 \%$ (15 joints) but 13 joints (46.4\%) from this group were found as diseased (see Table 3). 
Table 3: Cross table of the ratio of diseased and healthy hip joint statuses according to SHER and BHER methods

\begin{tabular}{|c|c|c|c|c|c|}
\hline \multirow{2}{*}{ Method } & & & \multicolumn{2}{|l|}{$\underline{\text { BHER }}$} & \multirow[b]{2}{*}{ Total } \\
\hline & & & Diseased & Healthy & \\
\hline \multirow{8}{*}{ SHER } & Diseased & Count & 70 & 2 & 72 \\
\hline & & $\%$ within SHERDiseased & $97,2 \%$ & $2,8 \%$ & $100,0 \%$ \\
\hline & & \% within BHERDiseased & $84,3 \%$ & $11,8 \%$ & $72,0 \%$ \\
\hline & & $\%$ of Total & $70,0 \%$ & $2,0 \%$ & $72,0 \%$ \\
\hline & Healthy & Count & 13 & 15 & 28 \\
\hline & & $\%$ within SHERDiseased & $46,4 \%$ & $53,6 \%$ & $100,0 \%$ \\
\hline & & $\%$ within BHERDiseased & $15,7 \%$ & $88,2 \%$ & $28,0 \%$ \\
\hline & & $\%$ of Total & $13,0 \%$ & $15,0 \%$ & $28,0 \%$ \\
\hline \multirow[t]{4}{*}{ Total } & & Count & 83 & 17 & 100 \\
\hline & & \% within SHERDiseased & $83,0 \%$ & $17,0 \%$ & $100,0 \%$ \\
\hline & & \% within BHERDiseased & $100,0 \%$ & $100,0 \%$ & $100,0 \%$ \\
\hline & & $\%$ of Total & $83,0 \%$ & $17,0 \%$ & $100,0 \%$ \\
\hline
\end{tabular}

Legend: SHERKG: Standard Hip Extended, BHERKG: Balanced Hip Extended

\section{DISCUSSION}

To the author's knowledge, this is the first study in which the measurement of applied extending loads in standard ventro-dorsal hip-extended radiography was utilized and their effects have been evaluated. In this study, a study group of 50 dog's 100 hip joints were evaluated with NoA evaluation for the diagnosis of CHD. All dogs were chosen randomly from big and giant breeds (mean body weight was $31.38 \mathrm{Kg}$, Labrador retriever (26\%), German Shepherd (12\%), English Bulldog (10\%), Shar Pei (6\%), Newfoundland $(6 \%))$ when they were brought for CHD control to clinics by their owners. The anesthesia protocol was standardized due to uniformity in muscle relaxation, which is found crucial according to related studies (Genevois et al. 2006, Todhunter et al. 2003) when assessing subjective data e.g. when measuring coxometric values such as NoA (Genevois et al. 2006) in scoring hip joints. The evaluations were made by radiology and biomechanical analysis was not conducted. The inter-observer bias was not appointed since all radiographs were evaluated by the same scrutinizer using a standard measuring template as shown in related studies (Verhoeven et al. 2007, Verhoeven et al. 2009).

FCI grading system is found to be the most reliable method at the mean age of 244 days, with high negative and positive predictive values (Ohlerth et al. 2003). The PennHip and distraction index method are found very sensitive techniques in predicting true negatives but both techniques have been found to overestimate the fraction of dysplastic dogs at the age of 384 days which would lead to the elimination of a high proportion of working dogs, therefore a combination of both methods is offered to select the dogs whether for breeding or working (Reagan 2017). The use of 105 degrees of NoA threshold value would result in high false-negative diagnoses in German Shepherd dogs and cause to the removal of the dogs from the gene pool that is not CHD susceptible which is found counterproductive (Culp et al. 2006, Reagan 2017, Yaprakci and Tekerli 2015). Our study group means age was 20.4 months (612 days) which is found in term the CHD expression is conclusive (Manley et al. 2007).

Within the results, BHER method showed significantly lower (mean: 1, $97 \mathrm{~kg}$ SE: 0,04722) loads compared to SHER method (mean: 4, $17 \mathrm{~kg}$ SE: $0,21814) \mathrm{p}<.001, \mathrm{r}=-0.72$. The difference of loads between hip sides (SHERKg Right and Left \& BHERKg Right and Left) were not found significant $(\mathrm{p}>.05)$ in both techniques but there was significant difference between methods SHERKg and BHERKg where BHERKg mean was significantly lower on both sides comparing to SHERKg. Conversely, our data confirmed that, even if there is no significant difference occurred in extending loads between hip sides, balancing these loads caused a significant difference in NoA values between tested methods (SHERNoA - BHERNoA; $z=-5.089, \mathrm{p}<.001, \mathrm{r}=$ $0.76)$.

The linear relationship and strong effect size confirm the corroboration between SHER and BHER techniques in which the 72 diseased hip joints of SHER method was also found $97.2 \%$ diseased by BHER method. In the healthy group of SHER method which the 28 healthy hip joints were later found 46\% (13 hip joints) diseased by BHER method. The true positives of SHER method were common between methods by $17 \%$ but $2.8 \%$ of disparity was occurred in BHER method (Table 3).

The hip laxity may change due to patients positioning which leg extension twists the hip joint capsule resulting in forcing the femoral heads into the acetabulum (Farese et al. 1998, Gaspar et al. 2016). 
Bilateral symmetry of pelvis is seen altered unacceptably depending on pelvic rotation as shown in a study (Gaspar et al. 2016). In our study the positioning was set the same in both techniques. Advancement of the disease causes the thickening of the joint capsule (Corfield et al. 2007) and changes the subluxation degree of femoral heads. We believe that balancing the extending loads on hip sides prevented the shift of excessive load on to opposite side of the hip which was proven to cause a radiographical error in the observation of coxometric values.

\section{CONCLUSION}

The results of this study indicate the corroboration of both methods with strong and positive correlation in true diagnoses that was shown the sensitivity of BHER method. The results of NoA evaluation with BHER method showed higher sensitivity compared to SHER method. Even when a lower force was applied, the subluxations were found significantly higher than those in SHER. Higher sensitivity of BHER method may let better diagnosis of hip joint laxity, and the conclusion of this study is BHER method was found to be more reliable method in the diagnosis of CHD.

\section{ACKNOWLEDGMENT}

This survey was conducted in the form of an oral presentation in Veterinary Orthopedy and Traumatology Association Congress IV (VOTDER) in 2017. This study received no grant from any of institutions.

The authors would like to acknowledge Dvm. Doğukan Özen and Dvm. Kasia Siewruk for their supports in this study. The device's configuration used for Balanced Hip Extended Radiography procedure was protected under the patent registration number 2009/05202 in Turkish Patent Institute.

Conflict of Interest: Authors declare no conflict of interest.

Author Contributions: M.V.Y.; development of the concept of balancing the applied loads on radiography, designing the experimental setup, performing tests, evaluation of the statistical results, manuscript preparation and submission

M.G.; designing the experimental setup, performing tests, evaluation of the statistical results

\section{REFERENCES}

Adams, W. M., R. T. Dueland, J. Meinen, R. T. O'brien, E. Giuliano and E. V. Nordheim (1998). "Early detection of canine hip dysplasia: Comparison of two palpation and five radiographic methods." J Am Anim Hosp Assoc 34(4): 339-347.
Corfield, G. S., R. A. Read, K. A. Eastley, J. L. Richardson, I. D. Robertson and R. Day (2007). "Assessment of the hip reduction angle for predicting osteoarthritis of the hip in the labrador retriever." Aust Vet J 85(6): 212-216.

Culp, W. T., A. S. Kapatkin, T. P. Gregor, M. Y. Powers, P. J. Mckelvie and G. K. Smith (2006). "Evaluation of the norberg angle threshold: A comparison of norberg angle and distraction index as measures of coxofemoral degenerative joint disease susceptibility in seven breeds of dogs." Vet Surg 35(5): 453-459.

Dueland, R. T., W. M. Adams, J. P. Fialkowski, A. J. Patricelli, K. G. Mathews and E. V. Nordheim (2001). "Effects of pubic symphysiodesis in dysplastic puppies." Vet Surg 30(3): 201-217.

Farese, J. P., R. J. Todhunter, G. Lust, A. J. Williams and N. L. Dykes (1998). "Dorsolateral subluxation of hip joints in dogs measured in a weight-bearing position with radiography and computed tomography." Vet Surg 27(5): 393-405.

Gaspar, A. R., G. Hayes, C. Ginja, M. M. Ginja and R. J. Todhunter (2016). "The norberg angle is not an accurate predictor of canine hip conformation based on the distraction index and the dorsolateral subluxation score." Preventive Veterinary Medicine 135: 47-52.

Genevois, J. P., T. Cachon, D. Fau, C. Carozzo, E. Viguier, F. Collard and D. Remy (2007). "Canine hip dysplasia radiographic screening. Prevalence of rotation of the pelvis along its length axis in 7,012 conventional hip extended radiographs." Vet Comp Orthop Traumatol 20(4): 296-298.

Genevois, J. P., G. Chanoit, C. Carozzo, D. Remy, D. Fau and E. Viguier (2006). "Influence of anaesthesia on canine hip dysplasia score." J Vet Med A Physiol Pathol Clin Med 53(8): 415-417.

Genevois, J. P., D. Remy, E. Viguier, C. Carozzo, F. Collard, T. Cachon, P. Maitre and D. Fau (2008). "Prevalence of hip dysplasia according to official radiographic screening, among 31 breeds of dogs in france." Vet Comp Orthop Traumatol 21(1): 21-24.

Henry, G. A. (1992). "Radiographic development of canine hip dysplasia." Vet Clin North Am Small Anim Pract 22(3): 559-578.

Manley, P. A., W. M. Adams, K. C. Danielson, R. T. Dueland and K. A. Linn (2007). "Long-term outcome of juvenile pubic symphysiodesis and triple pelvic osteotomy in dogs with hip dysplasia." J Am Vet Med Assoc 230(2): 206-210.

Meomartino, L., G. Fatone, A. Potena and A. Brunetti (2002). "Morphometric assessment of the canine hip joint using the dorsal acetabular rim view and the centre-edge angle." J Small Anim Pract 43(1): 2-6.

Ohlerth, S., A. Busato, M. Rauch, U. Weber and J. Lang (2003). "Comparison of three distraction methods and conventional radiography for early diagnosis of canine hip dysplasia." J Small Anim Pract 44(12): 524-529.

Reagan, J. K. (2017). "Canine hip dysplasia screening within the united states: Pennsylvania hip improvement program and orthopedic foundation for animals hip/elbow 
database." Veterinary Clinics of North America: Small Animal Practice 47(4): 795 - 805.

Risler, A., J. M. Klauer, N. S. Keuler and W. M. Adams (2009). "Puppy line, metaphyseal sclerosis, and caudolateral curvilinear and circumferential femoral head osteophytes in early detection of canine hip dysplasia." Vet Radiol Ultrasound 50(2): 157-166.

Smith, G. K., T. P. Gregor, W. H. Rhodes and D. N. Biery (1993). "Coxofemoral joint laxity from distraction radiography and its contemporaneous and prospective correlation with laxity, subjective score, and evidence of degenerative joint disease from conventional hipextended radiography in dogs." Am J Vet Res 54(7): 1021-1042.

Thompson, R., S. C. Roe and I. D. Robertson (2007). "Effects of pelvic positioning and simulated dorsal acetabular rim remodeling on the radiographic shape of the dorsal acetabular edge." Vet Radiol Ultrasound 48(1): 8-13.

Todhunter, R. J., J. E. Bertram, S. Smith, J. P. Farese, A. J. Williams, A. Manocchia, H. N. Erb, N. L. Dykes, N. I. Burton-Wurster and G. Lust (2003). "Effect of dorsal hip loading, sedation, and general anesthesia on the dorsolateral subluxation score in dogs." Vet Surg 32(3): 196-205.

Verhoeven, G., F. Coopman, L. Duchateau, J. H. Saunders, B. Van Rijssen and H. Van Bree (2007). "Interobserver agreement in the diagnosis of canine hip dysplasia using the standard ventrodorsal hip-extended radiographic method." J Small Anim Pract 48(7): 387-393.

Verhoeven, G. E., F. Coopman, L. Duchateau, T. Bosmans, B. Van Ryssen and H. Van Bree (2009). "Interobserver agreement on the assessability of standard ventrodorsal hip-extended radiographs and its effect on agreement in the diagnosis of canine hip dysplasia and on routine fci scoring." Vet Radiol Ultrasound 50(3): 259-263.

Yaprakci, M. V. and M. Tekerli (2015). "Köpeklerde kalça displazisine yol açan kalıtsal ve çevresel faktörler üzerine bir derleme." Lalahan Hayvancilik Araştirma Enstitüsü Dergisi 55(1): 37 - 43. 